Rebels and Mafiosi 



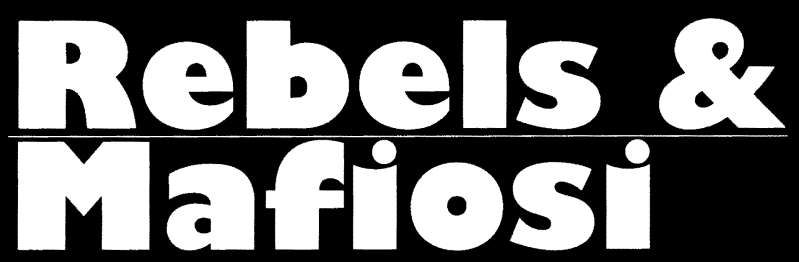

Death

in $\mathbf{a}$

Sicilian

Landscape

\section{JAMES FECTRESS}

Cornell University Press

ITHACA AND LONDON 
Copyright (C) 2000 by Cornell University

All rights reserved. Except for brief quotations in a review, this book, or parts thereof, must not be reproduced in any form without permission in writing from the publisher. For information, address Cornell University Press, Sage House, 5 I 2 East State Street, Ithaca, New York 14850.

First published 2000 by Cornell University Press

Printed in the United States of America

Library of Congress Cataloging-in-Publication Data

Fentress, James

Rebels and mafiosi : death in a Sicilian landscape / James Fentress.

p. cm.

ISBN o-8014-3539-o (cloth)

r. Mafia-Italy-Sicily-History. 2. Revolutions-Italy-Sicily-History-rgth century.

3. Government, Resistance to-Italy-SicilyHistory-Igth century. 4. Sicily (Italy)-Social conditions. 5. Crime-Italy-Sicily-History. $\mathrm{HV}_{453} . \mathrm{I}_{3} \mathrm{M}_{34}{ }_{5} 2000$

364. I' 06 'o $9458-\mathrm{dc2}$ I $99^{-05504 \mathrm{I}}$
Cornell University Press strives to use environmentally responsible suppliers and materials to the fullest extent possible in the publishing of its books. Such materials include vegetable-based, low-VOC inks and acid-free papers that are recycled, totally chlorine-free, or partly composed of nonwood fibers. For further information, visit our website at www.cornellpress.cornell.edu.
Cloth printing

$\begin{array}{llllllllll}10 & 9 & 8 & 7 & 6 & 5 & 4 & 3 & 2 & \text { I }\end{array}$ 